\title{
NATIVE CHILDREN AND THE CHILD WELFARE SYSTEM IN CANADA
}

\section{CHRISTINE DAVIES, Q.C.}

This article is comprised of a speech given by Professor Davies at the World Conference of the International Society on Family Law, held in 1991 in Yugoslavia. The professor leads into her discussion by reviewing the dismal statistics that face native people in Canada. The author suggests that the government's past approach, namely that of assimilation, combined with funding squabbles between the federal and provincial governments have been largely responsible for Canada's native child welfare problems. More recenty, a new antitude of cooperation has emerged between the government and native leaders. The result has been increased autonomy for native people in the area of child welfare and a greater sensitivity of the government to native concerns and cultural differences. While the author contends these changes are positive. she stresses that the autonomy of the native community must not infringe on the best interests of the child.
Le présent article inclut un discours prononcé par la professeure Davies lors de la Conférence mondiale de la Société internationale du droit familial, qui a eu lieu en Yougoslavie en 1991. La professeure Davies commence par examiner les statistiques consternantes relatives aux autochtones du Canada. L'auteure suggère que lapproche passcé du gouvernement. celle de lassimilation, associce aux querelles d'argent qui opposemt les gouvernements provinciaux et fédéral, sont largement responsables des problèmes de bien-être social que subissent les enfants autochones. Plus récenment. une nourelle atrinude do coopération émerge entre le gowernement et les chefs autochtones. Elle se traduit par une automomic croissamte des peuples autochtones dans le domuine du bien-être de renfance; pour sa part. le gouvernement se montre plus sensible aux préoccupations et aux différences culturelles autochtones. Tout en affirmant que ces changements sont positifs. Iauteure souligne que rautonomie de la communauté autochtone ne peut se faire at détriment de l'imérêt de l'enfant.

\section{TABLE OF CONTENTS}

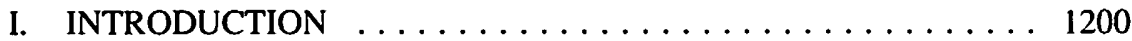

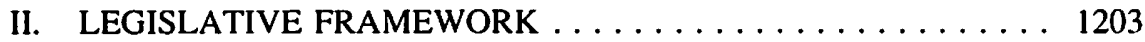

III. APPLICATION OF THE LAW:

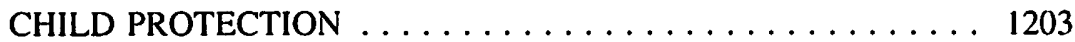

IV. THE WINDS OF CHANGE $\ldots \ldots \ldots \ldots \ldots \ldots \ldots \ldots \ldots$.

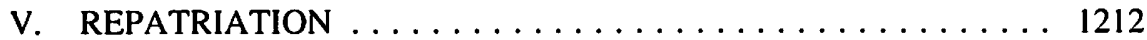

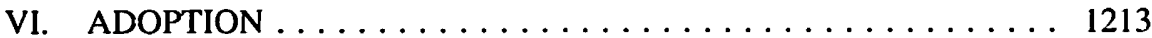

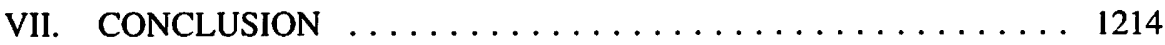

\section{INTRODUCTION}

The native population of Canada can be divided roughly into four groups:

Professor of Law, University of Alberta, Edmonton, Alberta. This paper was presented at the VIIth World Conference of the International Society on Family Law, Opatija, Yugoslavia (May, 1991). The author would like to thank Mr. Tony Mandamin for the benefit of his opinions. 
a) Status Indians are those registered or entitled to be registered under the Indian Act. ${ }^{\prime}$ Status Indians are given certain rights and benefits under the Indian Act. There are approximately 416,000 status Indians in Canada. ${ }^{2}$

b) Non-status Indians are those who by choice, or by operation of the Indian Act have given up or lost their status so that they no longer obtain the rights and benefits given by the Indian Act $^{3}$ There are approximately 75,000 non-status Indians in Canada. ${ }^{4}$

c) Metis. There are at least two different views about the meaning of the term "Metis." Some maintain that the term refers to those of aboriginal ancestry who are descended from the historic Metis community of Western Canada. Others say that Metis refers to anyone of mixed aboriginal ancestry who identifies him or herself as a Metis as distinct from Indian or Inuit. ${ }^{5}$ There are approximately 60,000 Metis in Canada. ${ }^{6}$

d) Inuit. (Originally called Eskimo). These aboriginal people live mainly in Canada's North. There are approximately 27,000 Inuit in Canada.?

The traditional ways of the native people have suffered over recent years. This is for a number of reasons. Living off the land and sea has become increasingly difficult given today's growing consumer society. A move away from the reserves and into urban centres, assimilation of the white culture, the prevalence of alcohol and disease and the insidious effect of social assistance have all taken their toll. The result is not a happy one. Aboriginals are caught in a cross-current of cultures, not readily able to adapt to (or be accepted by) white society but having increasingly lost touch with their past traditions. The figures are depressing:

- there is a $30 \%$ chance of an Indian being born in a single parent family, compared to $12 \%$ for non-Indians;

- the infant mortality rate among Indians is four times higher than it is for non-Indians;

- an Indian mother will have at least twice as many children as a non-Indian mother - an Indian child's life expectancy is ten years shorter than that of a non-Indian child;

\section{R.S.C. 1985 , c. I-5.}

Canadian Social Trends, Winter 1988 (Statistics Canada) at 11.

E.g. prior to a recent amendment to the Indian Act an Indian woman who married a non-Indian man lost her status. When status Indians were prohibited from voting in elections some gave up their status in order to obtain the right to vote.

Supra, note 2 at 11.

Ibid. at 15.

Ibid. at 11.

Ibid. at 11 . 
- there is a $50 \%$ chance that the Indian child will not complete grade nine, compared to a $10 \%$ chance for a non-Indian child;

- the Indian youth has a $10 \%$ chance of graduating from high school, compared to $43 \%$ for a non-Indian youth. It has been suggested that an Indian youth is more likely to go to jail than to complete high school;

- there is one chance in three that Indians will be unemployed for most of their lives. If they are employed, it will probably be in a manual capacity, and it will be seasonal or short-term work;

- it is thirteen times more likely that an Indian will live in a crowded home (which is defined as more than one person per room);

- an Indian is ten times more likely to die of tuberculosis than a non-Indian. Between the ages of 5 and 14, the rate of tuberculosis is 27 times that of non-Indians;

- an Indian is five times more likely to commit suicide than a non-Indian.

- Indians are 8 to 10 times more likely to suffer from a sexually transmitted disease during their life-time than are non-Indians;

- there is a $35-40 \%$ chance that an Indian will suffer from alcohol abuse, and a $20-25 \%$ chance of suffering from drug abuse;

- an Indian is susceptible to hepatitis, gastro-intestinal and respiratory infections, diabetes, all forms of heart disease and cancer at a much higher rate than a non-Indian;

- an Indian is three times more likely to die as a result of an accident, violence, or poisoning than is a non-Indian;

- an Indian is three times more likely to be committed to a young offender centre than is a non-Indian. ${ }^{8}$

The native leaders are well aware of the plight of their people and there is a fierce effort to regain autonomy over their own lands, their own lives and their own people.

Our concern is not with natives generally but specifically with native children. One can readily see that the clash of two cultural systems has the potential for catching children in the middle. Unfortunately, as we shall see, this is indeed what has happened. 
Indian parenthood and a native child's cultural identity have for years been treated in a cavalier fashion. Today, the merits of keeping a child within his or her family and within his or her community are recognized and fostered. Involvement of the Indian community in the Child Welfare system as it relates to Indian children has, for the most part, been a positive development. A number of thorny questions remain to be answered, however. They are these. When the child's relationship with his or her natural parents has been severed and that child has now bonded with a new family, one that does not share his or her native background and heritage, should the factor of cultural identity outweigh the factor of psychological bonding? How does the child's emotional bond with a psychological parent fare against his need to be brought up in a native community? What weight on the scales should be given to the needs of an Indian Band to preserve its own culture and heritage?

\section{LEGISLATIVE FRAMEWORK}

Under s.91(24) of the Constitution Act, 1867 the Federal Government has legislative jurisdiction over Indians and land reserved for Indians. In 1951, the Indian Act was amended to provide that laws of general application that are in force in a province are applicable to Indians except where such laws are inconsistent with the Indian Act itself or with a treaty between Indians and the Crown." Pursuant to this provision, both provincial child protection legislation and provincial adoption legislation have generally been held to apply to Indians. ${ }^{10}$ Thus, provincial adoption legislation applies to Indian children, but an Indian child adopted by non-Indians does not lose his Indian status. Provincial legislation that states:

For all purposes an adopted child becomes upon adoption the child of the adopting parent...

is applicable to Indians only in so far as it does not conflict with federal legislation. If it were to deprive a child of his Indian status, then there would be a conflict. Thus, the provision is construed so as to make the child that of the adopting parent, save for depriving him of status and that which goes to his essential Indian character and identity."

\section{APPLICATION OF THE LAW: CHILD PROTECTION}

Until very recently the history of Indian child welfare has been a history of attempted assimilation. As was stated in a report on Indian and Metis adoptions and placements in Manitoba,

[F]or the past two hundred years the children of Indians have been the innocent victims of a cultural war waged against them by society. Christian missionaries, Indian Agents, school teachers, and politicians have all argued that Indian children must be taught to be something other than Indian, to be something

4. R.S.C. 1985 , c. I-5, s. 88 .

11. Natural Parents v. Superintendent of Child Welfare (1976), 60 D.L.R. (3d) 148 (S.C.C.); Nelson v. C.A.S. of Eastern Manitoha, [1975] 5 W.W.R. 45 (Man.C.A.).

II. Natural Parents v. Superintendent of Child Welfare, ibid. 
they are not and never can be. These perceived pillars of society have tried, usually misguidedly, but nevertheless relentlessly, to indoctrinate in these children the belief that the customs, the values and traditions of their people must be discarded if Indians were ever to take their place in the majority community. To achieve this goal, children were removed from their homes and placed arbitrarily in residential schools with only brief continuing contact with their families. More recently children have been removed and placed in non-aboriginal, middle class homes for adoption. While neither the literature nor the research into this issue is as yet extensive, indications are that children are subject to periods of identity crisis particularly during their teenage years. Over the past years, these collective efforts have profoundly scarred the hearts and minds of too many Indian people. ${ }^{12}$

Teaching Indian children the "white man's way" and concurrently discouraging the traditional beliefs and way of life was the path followed by missionaries and settlers in the nineteenth century. Right up to the 1970s, aboriginal children were taken from their communities to residential schools where they were deprived of the influence of their communities and discouraged (often harshly) from speaking their own language and practising their own beliefs and customs. Until the latter part of the 1940s, it was rare for either provincial government or private child welfare services to be offered on reserves. In a severe case, the Indian Agent would place the child with another family on the reserve or, if the child were older, send him or her to a residential school. ${ }^{13}$

When the Indian Act was amended in 1951 to provide that provincial laws of general application were usually applicable to Indians, concern was felt by both provincial child welfare authorities and by Indian leaders, but for very different reasons. ${ }^{14}$ The provincial child welfare authorities were reluctant to extend their services onto reserves unless the federal government provided funding which it seemed less than eager to do. The Indian leaders did not want white provincial social workers interfering in reserve life. Thus, despite the obvious applicability of provincial child welfare legislation, the child welfare authorities did little on reserves except in the most extreme cases. ${ }^{15}$

In recent years the federal government has softened its attitude. It has begun to reimburse some of the provinces and has also funded some Indian Bands under child welfare agreements. The services today, however, are still inconsistent. The extent to which provincial child welfare services are provided on a reserve will depend on the government agreement in existence. The dispute between federal and provincial authorities over funding has been described by one native writer as follows:

12. Manitoba, Interim Report of the Review Committec on Indian and Metis Adoptions and Placements, No Quiet Place, (Manitoba: Manitoba Community Services, 1983) (Associate Chief Judge E.C. Kimelman, Chairman) at 5.

13. H.B. Hawthorn and M.A. Tremblay, "A Survey of the Contemporary Indians of Canada" (Ottawa: Indian Affairs Branch, 1966) at 326. See also J.A. MacDonald, "The Spallumcheen Indian Band Bylaw and Its Potential Impact on Native Indian Child Welfare Policy in British Columbia" (1983) 1 Canadian Joumal of Family Law 75 at 77.

H. See text accompanying footnotes 9 and 10.

15. M. Sinclair, D. Phillips \& N. Bala, "Aboriginal Child Welfare in Canada" in Bala, Homick and Vogl, eds., Canadian Child Welfare Law (Toronto: Thompson Educational Publishers, 1991) at 185. See also S.A. Bull, "The Special Case of the Native Child" (1989) 47 Advocate 523. 
The federal and provincial government squabbles are like two elephants fighting; it is the grass that gets

battered, tom and uprooted; the Indian child is the grass, a victim of this enormous battle. ${ }^{16}$

Meanwhile, since the 1950s, the number of aboriginal children in care has grown at an alarming rate and is only now starting to decrease. For instance, in 1985-86, Indian children were placed into care on average 2.7 times as often as other children across the country. ${ }^{17}$ A study in 1977 showed that native children represented about half the children in care in the Western provinces and almost $20 \%$ of all children in care across Canada. $^{18}$

What is the reason for these disproportionate figures? Several possibilities have been advanced:

1. Apprehensions are frequently carried out by white social workers with little or no understanding of the cultural background of the child or the very different methods of child rearing in Indian communities. ${ }^{19}$

2. It is a well documented fact that Indians in Canada experience a higher level of unemployment than non-natives. According to the 1981 Census, only half of the adult native population under age 65 was in the labour force compared to $2 / 3$ of non-natives. ${ }^{20}$ High levels of unemployment translate into poverty, poor, overcrowded housing and

S.A. Bull, ibid. at 524.

17. Canada, Final Report, Indian and Northern Affairs Canada, Child and Family Services Task Force. Indian Child and Family Services in Canada (Indian and Northern Affairs Canada, 1987) at 14.

H.P. Hepworth, Foster Care and Adoption in Canada (Otlawa: Canadian Council on Social Development, 1980) at 121. See also, Alberta, Recommendations from the Working Committee on Native Child Welfare, In the Imterest of Native Child Welfare Services (Edmonton, April 1987) at 9. which reports that in 1984 native children were six and half times more likely to receive child protective services than other children in Alberta.

These differences are discussed by E.F. Carasco, "Canadian Native Children: Have Child Welfare Laws Broken the Circle?" (1986) 5 Canadian Journal of Family Law 111 at 114, and by S.A. Bull. supra, note 15 at 527-528; M. Sinclair, D. Phillips and N. Bala, supra, note 15 at 176-177; Canadian Council on Social Development. Native Children and the Child Welfare System. by P. Johnson (1983) at $68 \mathrm{ff}$.

Further, Indians are culturally biased to operate by consensus. This means that they tend to refrain from imposing decisions on individual Indians until there is substantial agreement on a course of action. A corollary is that individual Indians tend to be patient in waiting for issues to resolve. As a result, Indian families and relatives often do not question or challenge persons in authority but wait for the outcome of the actions of the authority figures.

When a child is apprehended. the parents or relatives are usually expected to put forth their position. When an Indian child is apprehended, the Indian parents or relatives tend not to press for their position in relation to the child against the intrusive actions of the child welfare authorities or if they do so their efforts are relatively ineffective. By the time any issue is raised, so much time has lapsed that the Indians' position has eroded. 
welfare dependency. Studies have shown a correlation between chronic poverty and child neglect. ${ }^{21}$

3. Native families tend to be larger than non-native families. A study in 1974 showed that $52 \%$ of Indian women had 4 or more children compared to $21 \%$ in the total population. ${ }^{22}$ A recent Alberta Report points out that the Indian birth rate is 2 to 3 times higher than the nonIndian birth rate. ${ }^{23}$

The 1986 Census shows that $46.8 \%$ of the native population is under the age of 19 years compared with $29.1 \%$ of the total population. ${ }^{24}$ Thus, there are almost as many children as adults in the native population. ${ }^{25}$

Native families are frequently headed by a single female parent. In 1981 single female headed families comprised $17 \%$ of all native families compared with $9 \%$ of all non-native families in Canada. ${ }^{26}$ Further, the 1981 Census showed native single parent families headed by mothers had incomes of only $58 \%$ of their non-native counterparts. $^{27}$

As one writer has put it:

I believe it is the single parent native family often headed by a mother who has given birth at a young age to one or more children out of wedlock, that is most adversely affected by chronic poverty, adult male exploitation and social isolation both on Indian reserves and urban communities. ${ }^{28}$

21. A Report by the National Council of Welfare on the Child Welfare System in Canada, In the Best Interests of the Child (Otlawa: National Council of Welfare, 1979). See generally J.A. MacDonald, "Child Welfare and the Native Indian Peoples of Canada" (1985) 5 Windsor Yearbook of Access to Justice 284 at 287-288 and P. Johnston, supra, note 19 at 74 et sq.

22. A Report Prepared for the British Columbia Royal Commission on Family and Child Law, The Social and Economic Conditions of Indian Families in British Columbia, by W.T. Stanbury (Vancouver, 1974). See generally, J.A. MacDonald, "The Spallumcheen Indian Band By-law and Its Potential Impact on Native Indian Child Welfare Policy in British Columbia" (1983) 1 Canadian Journal of Family Law 75 at 81 .

23. Supra, note 8 at 8-56.

24. Statistics Canada, Census 1986, Focus on Canada, Canada's Youth at 15.

25. The fact that there are almost as many children as adults in the native population, together with the poor economic plight of natives generally, (referred to above) means that there are few native foster homes. H.P. Hepworth. supra, note 18 at 118.

26. See also Justice on Trial, supra, note 8 at $8-56$, which reports that there is a $30 \%$ chance of an Indian being born in a single parent family, compared to $12 \%$ for non-Indians.

27. Statistics Canada, Census and Household Statistics Branch, Profile of Native Women 1981 Census of Canada (Ottawa: Minister of Supply and Services, 1984) 13. See also J.A. MacDonald, supra, note 21 at 288. 
4. The residential school system with its attendant encouragement of young native people to devalue their native ancestry drove a wedge between generations. This wedge caused difficulties in parenting both for the parents of the school attendees and for the attendees themselves. ${ }^{29}$

5. From the 1950 s (when provincial child welfare services were held to be applicable to Indians on reserves) until the mid 1970s (when changes started to be implemented), the activities of the welfare authorities took a somewhat rigid form. Native children believed to be in need were apprehended and placed in foster homes off of the reserve. There was little if any attempt to develop family support services or child placement resources on the reserves themselves. The results of this policy were disastrous. Hundreds of native children were taken from their homes and placed in foster homes that were culturally and racially different from the child's own background. Bands were decimated. The children were often lost to the Band and frequently lost their own feelings of identify and self-worth resulting in anti-social behaviour and suicide. $^{30}$ A native child, once taken into care, is less likely to be returned to his family than is a non-native child. Further, a native child who has been taken into care is less likely to be adopted than his nonnative counterpart. Hence, a continuous circle of foster care placements takes its disastrous toll. ${ }^{31}$

\section{THE WINDS OF CHANGE}

By the mid 1970s, it was apparent that the child welfare system, as it had been applied to native children, was catastrophic. The term "cultural genocide" was employed to describe the decimation of Indian communities that resulted from taking the young people away and depriving them of exposure to traditional culture. ${ }^{32}$ Indian leaders were concerned not only about what was happening to their people, but what was also happening to their communities with so many of the youth being brought up virtually ignorant of their cultural heritage. The mid 1970s saw cooperation among federal and provincial governments and native leaders in an attempt to involve native communities in the provision of child welfare services both on and off reserves. This involvement has taken various forms. Perhaps the most dramatic form is seen in the Spallumcheen Indian Band Child Welfare By-law. ${ }^{33}$ The Spallumcheen Indian Band occupies a reserve in the

J.A. MacDonald, ibid. at 288-289. See also Indian Association of Alberta, "Child Welfare Needs: Assessment and Recommendations" (1987) at 67.

30.

An Indian is five times more likely to commit suicide than a non-Indian, Justice on Trial, supra, note 8 at 8-56.

31. P.A. Monture, "A Vicious Circle: Child Welfare and the First Nations" (1989) 3 Canadian Journal of Women and the Law 1 at 3; E.F. Carasco. supra. note 19 at 114: H.P. Hepworth, supra, note 18 at 118.

32. See particularly, No Quiet Place, supra, note 12. Sec also P.A. Monture, ibid. at 3.

33. The history of this By-law and its content is discussed fully by J.A. MacDonald in two articles, supra, note 13 and supra, note 21 . See also M. Sinclair, D. Phillips and N. Bala, supra, note 15 at 187-189. 
Okanagan Valley in British Columbia. It comprises approximately 400 members, over a hundred of whom reside off the reserve in neighbouring communities. During the 1970s, the Band experienced significant social disruption, unemployment, welfare dependency, alcohol dependency and petty crime. During that decade, 80 children were apprehended and admitted to the care of the British Columbia Superintendent of Child Welfare. This decimation of the Band by the exodus of this high percentage of its youth jolted the Band into dramatic action. After consulting with the British Columbian Union of Indian Chiefs, the Band enacted a By-law "for the care of our Indian children" which gave the Band exclusive jurisdiction with respect to the custody of a Band child whether on or off the reserve. The Federal Minister of Indian Affairs chose not to exercise his powers of disallowance of the By-law, despite its uncertain constitutional validity. ${ }^{34}$ Thus, the By-law came into effect September 3, 1980. After a highly publicized march on the residence of the Provincial Minister of Human Resources, the Provincial Government agreed to respect the authority of the Band as conferred by the By-law. The Spallumcheen Band, therefore, now has exclusive jurisdiction over the custody of Band children. The Federal Department of Indian Affairs funds the Band's child welfare program.

The principle difference between the Spallumcheen Band By-law and a provincial child welfare law is that a child may be apprehended by the Chief and Band Council or by any person authorized by them and brought before a meeting of the Chief and Band Council. Thus, the persons apprehending and the persons making the disposition are one and the same. In making a disposition, the Chief and Band Council are to be guided by Indian custom and preferences and, in the case of an older child, the child's wishes. If a child cannot be immediately returned to the family, placement is to be made according to the following order of preferences:
a) with a parent;
b) with a member of the extended family living on the reserve;
c) with a member of the extended family living on another reserve;
d) with a member of the extended family living off the reserve;
e) with an Indian living on the reserve;
f) with an Indian living off a reserve;
g) as a last resort - with a non-Indian living off the reserve.

However, in making a placement decision, the Chief and Band Council are required to give paramount consideration to the best interests of the child in question.

The By-law clearly has some advantages. First amongst these must be the involvement of the Band in decisions relating to Band children and a clear attempt to halt the exodus of Band children from the Indian community. Facets of the By-law have, however, been criticized. Professor J.A. MacDonald has said that there is a real concern over the

34. The constitutional validity of the By-law is discussed by J.A. MacDonald supra, note 13 at 91 and supra, note 21 at 290-292. See also S.A. Bull, supra, note 15 at 529, where the learned author states that other Bands have passed similar child welfare by-laws after Spallumcheen but they have been disallowed for the reason that the Federal Government believes them to be invalid. 
potential for arbitrary decision making when a Band Council is assigned interventative, judicial and child placement powers. ${ }^{35}$ Further, he said, "[s]ome Indians may question the capacity of a Band Council, frequently dominated by men, to render fair and impartial decisions in such a sensitive area as child custody."

One might add that this is particularly worrying when the concern of the Band is as much for the preservation of its own culture and heritage as for the needs of the individual child in question.

The Spallumcheen Band By-law provides the greatest autonomy to native peoples in the running of a child welfare system. However, it serves only a small group of Indians and the Federal Government has recently indicated that it will disallow any more of these By-law arrangements. ${ }^{37}$

Arrangements giving less autonomy but serving a far wider segment of the native population, are becoming increasingly common. These arrangements involve Indian Bands in the delivery of child welfare services and taking on administrative responsibilities vis-a-vis Indian children. These arrangements differ significantly from the Spallumcheen Band By-law in that the law to be applied is the provincial child welfare legislation and the courts that determine disposition are the Provincial Courts. Under these arrangements, the native communities are involved in service and administration, they do not make the laws nor are the courts native courts. To this extent the arrangements have been criticized. ${ }^{38}$ The fact that provincial child welfare laws are applied means that there is little or no recognition of customary laws and tradition. The use of the Provincial Courts has been unfavourably compared to the Tribal Courts which determine child welfare matters on reservations in the United States. ${ }^{39}$

A closer look at these "arrangements" reveals five main types: (1) An Agreement between the Federal Government and the Band (bi-partite); (2) An Interlocking Bipartite Agreement; Federal-Band/Provincial-Band; (3) A Tripartite Agreement between the Federal Government, the Provincial Government and the Band; (4) A Provincial/Band Agreement; and (5) A Federal/Provincial Agreement. ${ }^{40}$

All Bands are now covered under one type or another arrangement for the provision of child welfare services." ${ }^{41}$ Not only are there differences in the types of Agreement, there are also differences in the levels of transfer of responsibility and control. Some Bands are initially given only responsibility for the provision of prevention services (basically providing support for families "at risk"). As expertise and proficiency increase

J.A. MacDonald, supra, note 21 at 296-297.

J.A. MacDonald, supra, note 13 at 95.

M. Sinclair, D. Phillips and N. Bala, supra, note 15 at 189; S.A. Bull, supra, note 15 at 529.

See M. Sinclair, D. Phillips and N. Bala, supra, note 15 at 186; J.A. MacDonald, supra, note 21 at 300-301.

See text accompanying footnotes 67-70.

See generally, Indian Child and Family Services in Canada, supra, note 17 at 16.

Ibid. at 19. 
more responsibility is given to the extent that some Bands or group of Bands have control and responsibility for the provision of the full range of child welfare services mandated under the Provincial Act becoming, under the Service Agreement, an "Indian child and family services authority. ${ }^{142}$

Further, child welfare legislation of some provinces reflects greater sensitivity to native concerns and a recognition of the role played by the Band. For example, s. 73 of the Alberta Child Welfare Act provides that if the Director of Child Welfare has reason to believe that the child is an Indian, then consultation with the Chief of the Council or the Council of the Band should be sought before entering into a permanent Guardianship Agreement or applying for a Supervision Order or a temporary or permanent Guardianship Order in respect to the child. ${ }^{43}$ Similar provisions apply with respect to adoption. ${ }^{44}$

The Child Welfare Services $A c t^{45}$ of Manitoba provides in its preamble that Indian Bands are entitled to the provision of child and family services in a manner which respects their unique status as aboriginal peoples.

The Child and Family Services Act, of Ontario provides that one of the purposes of the Act is to recognize that Indian and native people should be entitled to provide, wherever possible, their own child and family services, and that services to Indian and native children and families should be provided in a manner that recognizes their culture, heritage and traditions and the concept of the extended family. ${ }^{46}$ Pursuant to Part X of the Act the Minister of Community and Social Services may enter into arrangements with Bands or native communities for the provision of child welfare services by an Indian or Native Child and Family Services Authority. If services are being provided to native children by a non-native agency, then that agency shall regularly consult with the appropriate Bands or native communities with respect to the provision of services. ${ }^{47}$

The legislation of British Columbia provides that where there is to be a hearing following apprehension, notice of the hearing must be given to the Band Manager or Band Social Development Officer of the Indian Band to which the child belongs if it appears that the child is registered or entitled to be registered as an Indian under the Indian Act. ${ }^{48}$ In Saskatchewan, under the Child and Family Services Act ${ }^{49}$ the court, at a protection hearing involving a status Indian child, may, on request, designate the Chief of the Band or his designate as a person having sufficient interest in the child. That person then becomes a party to the protection hearing. ${ }^{50}$ The Act goes on to say that in making a decision relating to placement, the officer or the court, shall regard the best interests of

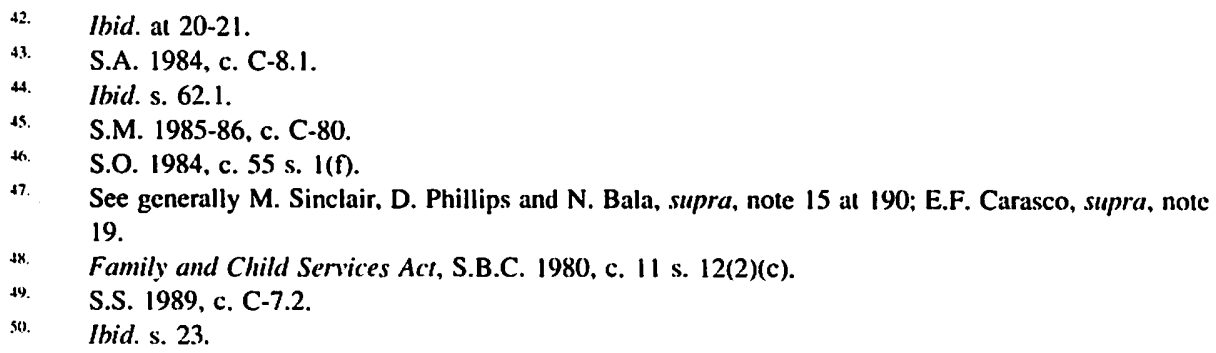


the child and, where practicable, attempt to maintain the child in an environment that is consistent with the child's cultural background. ${ }^{51}$ Finally, by s.61, the Minister assigned with responsibility for the administration of the Act is empowered, "having regard to the aspirations of people of Indian ancestry to provide services to their communities, enter into agreements with any legal entity for the provision of services or the adminstration of all or any part of this Act by that legal entity."

Case law to date has recognized a Band as having sufficient interest to intervene in custody and guardianship proceedings, ${ }^{52}$ but as not having status to apply for custody or guardianship for itself. ${ }^{53}$ However, these decisions all depend on the wording of the individual provincial statute.

Given the lack of consensus between the federal government and the various provinces over responsibility for Indian child welfare, and given also the widely different agreements between the three interested bodies (the federal government, the provincial government and the Bands themselves), and the differences in provincial legislation, it is not surprising that native involvement in child welfare varies widely across the country. Despite the differences, significant changes have been noted with respect to Band involvement generally: $:^{54}$

1. There are markedly fewer children in care under Band directed care than under Provincial Child Welfare Services. This is because Indian community care emphasizes prevention services addressed, not only to individual families, but to the community as a whole through information sharing, training etc..

2. When a child is placed in care through Band services, the placement is generally by consent. Under Band services parental consent is obtained in $60-95 \%$ of all placements. By contrast, under Provincial Child Welfare Services, court orders have been the predominant mechanism for placing a child in care. The high degree of consent with respect to Band placement is due to the fact that Indian community care involves a planning process involving parents, all the children and other family members working by consensus wherever possible. The approach taken by the Indian community to parents is generally non-judgmental and supportive. $^{55}$

3. Albeit both provincial child welfare authorities and Indian community services place most children in foster homes, provincial authorities are

51. Ihid. s. 53.

52. See Pitzel v. C.A.S. of Winnipeg, [1984] 5 W.W.R. 474 (Man.Q.B.) (decided prior to the enactment of the present Child and Family Services A(t).

53. Tom v. Winnipeg Children's Aid Sociesy. [1982] 2 W.W.R. 212 (Man.C.A.); Re C. and V.C. (1982), 40 B.C.L.R. 234 (Prov. Ct.).

ss. See Indian Child and Family Services in Canada, supra, note 17 at 8-11.

55. See also P.A. Monture, supra, note 31 at 6. 
more inclined towards placing children in group homes or institutions than are Indian Bands. Band placements into these settings comprise about $9 \%$ of all placements whereas for provincial agencies they comprise about $14 \%$ of all placements.

4. Almost all family home placements of Bands are made with the families in the community. Provincial agencies place most children outside the community. This is because Indian community care involves greater participation of the community as a whole, particularly the extended family in decision making.

5. Placing predominantly with consent and within the community results in shorter periods of care for Indian children placed by Bands.

6. Band services focus on the family as a whole and emphasize family support, both preventive and remedial. The community, the family, elders and other Band services are called in to aid the family. By contrast, provincial agencies focus their services upon the particular child. Little is done to remedy family problems.

\section{REPATRIATION}

In the post war years, Indians saw their youth being removed from their cultural roots and reared in white homes. Since the mid 1970s much has changed. Native people are more involved in decision making. Consequently, there are less apprehensions, more services supporting children within the family and, if removal of the child is necessary, then more likelihood of him being placed in a native foster or adoptive home. All this is to the good. However, what of children that were already established in white foster homes? These children were caught in the cross-currents of a changing philosophy. Alienated from their cultural heritage, it was too late for many of them to turn back. The press reported heart rending tales of "repatriation" - Indian children established in white homes suddenly uprooted and returned to a native culture that has become alien to them. ${ }^{56}$

A particularly horrendous case was that of Jane Doe v. Awasis Agency of Northern Alberta. ${ }^{57}$ This case caught the headlines in papers across the country. Jane was a native girl who had been adopted at the age of one by white parents. When she was fourteen the child was removed against her will from the adoptive parents by the for three years and was then removed by the Regional Children's Guardian and placed with an aunt on a reserve. The Regional Children's Guardian denied that the Government of Alberta followed a repatriation policy and the courts accepted her testimony. Nonetheless, the decision of the Regional Children's Guardian was quashed by the court. Subsequently, the Alberta Child Welfare Act was changed so as to eliminate the office of Children's Guardian and replace it with that of Children's Advocate.

57. (1990), 72 D.L.R. (4th) 738 (Man. Q.B.). 
defendant (a native child welfare agency). The Adoption Order was set aside at the instance of the defendant and the girl was sent to the care and custody of her natural parents on an isolated reserve in Northern Manitoba. For the ensuing six months the child lived what could only be described as a nightmare existence. She did not speak the Dene language and many of the reserve inhabitants, including her parents, did not speak English. Life on the reserve was foreign to her and she was treated as an outcast. On many occasions she was forcibly confined, raped and sexually assaulted by a number of the male inhabitants of the reserve. She contracted a venereal disease as a result of the sexual assaults and rapes.

She wrote of her plight to her former foster parents who contacted the defendants and attempted to seek assistance for her. The defendants did not come to the aid of the child. Ultimately, she was removed from the reserve by a fly-in doctor. She was hospitalized suffering from depression, adjustment disorder and venereal disease. She attempted suicide twice. A settlement of $\$ 75,000$ was reluctantly approved by the Court. The Court was of the view that the figure was too low, but that the child would be damaged by the further trauma of litigation.

\section{Earlier I quoted Samuel Bull's colourful statement:}

The federal and provincial government squabbles are like two elephants fighting; it is the grass that gets battered, torn and uprooted; the Indian child is the grass, a victim of the enormous battle. ${ }^{58}$

The Indian child, it seems, is not free from the battle. The participants change but the child remains the victim.

\section{ADOPTION}

We have seen that an adopted Indian child does not lose his or her status by virtue of the adoption. ${ }^{59}$ The Alberta Child Welfare Act specifically provides that a person who adopts an Indian shall take reasonable measures on behalf of the child that are necessary for the child to exercise any rights he may have as an Indian. Further, as soon as the child is capable of understanding his status as an Indian, the adoptive parent shall inform the child of his status. ${ }^{60}$

Until the mid 1970s, Indian children who were available for adoption were classified by child welfare authorities as "difficult to place." Little effort was made to find a home close to their original communities and many were placed in the United States. ${ }^{61}$ Since

\section{S.A. Bull, supra, note 15 at 524.}

See text accompanying footnotes 9-11.

Child Welfare Act, S.A. 1984, c. 8-1, s. 73(5).

As to the situation in Manitoba, see the highly critical report of Associate Chief Judge E.C. Kimeiman, No Quiet Place, supra, note 12. After reviewing the files of 93 native children who were placed out of province in 1981 for purposes of adoption, Judge Kimelman concluded that cultural genocide had been taking place in a systematic, routine manner. The placement of children out of province had not been an exception, it constituled a regular, ongoing practice. The placement of children had not been justified on the basis of age, sibling group size or special problems. (File 
the mid 1970s, we have seen a greater involvement of native communities in child welfare matters. Increasingly, native children are being placed in foster and adoptive homes within their own communities. What, however, of the native child who has been placed in a non-native adoptive home? What weight will the courts place on the child's ancestry in determining to grant or refuse an adoption?

The leading case on this issue is A.N.R. v. L.J.W. (Racine v. Woods) ${ }^{62}$ At age 6 weeks, the child had been placed in the care of non-native foster parents. She remained in their care almost continuously for six years when they applied to adopt her. The child's natural mother contested the adoption. The Supreme Court of Canada granted the adoption. In discussing the question of the child's Indian race and heritage, Wilson J. (who gave the judgment of the Court) said:

In my view, when the test to be met is the best interests of the child, the significance of cultural background and heritage as opposed to bonding abates over time. The closer the bond that develops with the prospective adoptive parents the less important the racial element becomes. ${ }^{63}$

This case has been criticized. One writer has called the case another "instance of the suppression and misinterpretation of first nations culture."64 However, it is submitted that such criticism is unfair. When the guiding principle is the best interest of the individual child, then race and culture must be weighed in the balance with all other factors. In another case, race and cultural identity might outweigh the fact of bonding. ${ }^{65}$ Much will depend on the length of time the child has been away from the home community, how long he or she has been with the proposed adopters and whether the proposed adopters are willing to expose the child to his or her Indian heritage etc. As Wilson J. said: "A child is not a chattel." ${ }^{16}$ A child should not be bestowed on an Indian parent because he or she is Indian any more than on a white parent because he or she is white. Rather, the sole consideration should be, "what is best for this particular child?"

\section{CONCLUSION}

In the United States the federal Indian Child Welfare Act provides that a Tribal Court has exclusive jurisdiction over "child custody proceedings" (broadly defined to include pre-adoptive and adoptive placement) if a child is domiciled or resident within the

Review Report, April 1984, at 51-52).

(1983), 36 R.F.L. (2d) 1 (S.C.C.).

Ibid. at 13.

64.

P.A. Monture, supra, note 31 at 14. See also E.F. Carasco, supra, note 19 at 124 and S.A. Bull, supra, note 15 at 526.

65. Compare N.(K.) v. M.(K.M.) (1989), 71 Alta L.R. (2d) 42 (Alta.C.A.) (affirming in part 97 A.R. 38 (Q.B.)) (leave to appeal to S.C.C. refused 30th of November 1989) where a two year old child who had been in the care of the proposed adoptive parents since birth was returned to her Vietnamese mother since genetic and cultural factors outweighed that of bonding. 
reservation of the Tribe. ${ }^{67}$ If the child is not so domiciled or resident a State Court shall transfer any proceeding to the Tribal Court in the absence of good cause to the contrary and absent objection by either parent. The Tribe has the right to intervene in any State Court proceedings regarding the child's custody. In either court the following rule applies:

In any adoptive placement of an Indian child under State law, a preference shall be given, in the absence of good cause to the contrary, to a placement with (1) a member of the child's extended family; (2) other members of the Indian child's tribe; or (3) other Indian families.

The rationale of the Act is twofold:

1. To promote the stability and security of Indian tribes. The large number of Indian children adopted by non-Indians threatened the continued existence and integrity of Indian tribes.

2. To avoid the damaging social and psychological impact on individual Indian children which is brought about by placements outside their culture. ${ }^{\text {** }}$

In Canada, our laws are steadily moving away from the concept of "parental rights" and focusing more on the best interests of the child. ${ }^{69}$ A child is seen less as a chattel in which a party has a proprietary interest and more as a unique person whose individual needs and wants should be paramount. ${ }^{70}$ The Indian Child Welfare Act of the U.S. involves the recognition of another right, that of the tribe. Canadian legislatures must think long and hard before they accept that a child's destiny should be determined, at least in part, by the rights of a party - a party whose rights may or may not coincide with the individual child's best interests. 